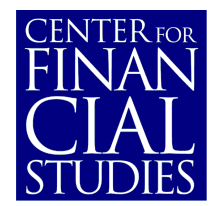

No. $2003 / 21$

\title{
Accounting for Financial Instruments in the Banking Industry: Conclusions from a Simulation Model
}

Günther Gebhardt, Rolf Reichardt, Carsten Wittenbrink

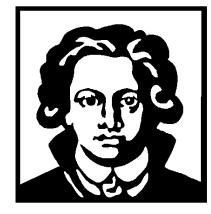

Center for Financial Studies 


\title{
Accounting for Financial Instruments in the Banking Industry: Conclusions from a Simulation Model
}

\author{
Günther Gebhardt*, Rolf Reichardt, Carsten Wittenbrink
}

December 2002

Revised: November 2003

\begin{abstract}
:
The paper analyses the effects of three sets of accounting rules for financial instruments - Old IAS before IAS 39 became effective, Current IAS or US GAAP, and the Full Fair Value (FFV) model proposed by the Joint Working Group (JWG) - on the financial statements of banks. We develop a simulation model that captures the essential characteristics of a modern universal bank with investment banking and commercial banking activities. We run simulations for different strategies (fully hedged, partially hedged) using historical data from periods with rising and falling interest rates.

We show that under Old IAS a fully hedged bank can portray its zero economic earnings in its financial statements. As Old IAS offer much discretion, this bank may also present income that is either positive or negative. We further show that because of the restrictive hedge accounting rules, banks cannot adequately portray their best practice risk management activities under Current IAS or US GAAP. We demonstrate that - contrary to assertions from the banking industry - mandatory FFV accounting adequately reflects the economics of banking activities.

Our detailed analysis identifies, in addition, several critical issues of the accounting models that have not been covered in previous literature.
\end{abstract}

JEL Classification: G21, M41

Keywords: Financial Instruments, Fair Value Accounting, Hedge Accounting, Accounting for Banks, IAS, US GAAP, Bank Simulation

\footnotetext{
* Corresponding author: Prof. Dr. Günther Gebhardt; Johann Wolfgang Goethe-Universität Frankfurt am Main; Professur für Betriebswirtschaftlehre, insb. Wirtschaftsprüfung; Mertonstraße 17 -25; 60054 Frankfurt am Main, Germany; Email: gebhardt@wiwi.uni-frankfurt.de

Rolf Reichardt; Landesbank Hessen-Thüringen Girozentrale; Main Tower, Neue Mainzer Str. 52-58; 60311 Frankfurt am Main, Germany; Email: Rolf.Reichardt@helaba.de Carsten Wittenbrink; Dresdner Bank AG; Jürgen-Ponto-Platz 1; 60301 Frankfurt am Main, Germany; Email: Carsten.Wittenbrink@dresdner-bank.com

Please note that the statements made by the authors herein do not necessarily represent the official opinions or positions of their respective institutions.
} 


\section{Introduction}

Advances in the economics and technology of banking and finance have led to a tremendous increase in the use of derivatives and other financial instruments. Accounting regulation had to follow these developments and all major standard setters have projects on their agendas to improve accounting for financial instruments.

Standard setters face strong opposition from the banking industry when proposing new standards that change their preferred "mixed model" by introducing fair value measurements for all derivative instruments (SFAS 133, IAS 39) or extending fair value accounting to all financial instruments, as recommended by the Financial Investments Joint Working Group of Standard Setters (hereafter JWG) ${ }^{1}$. Representatives of the banking industry argue that the proposals or standards do not adequately portray the economics of the banking business. ${ }^{2}$

The objectives of this paper are to carefully analyse and evaluate the arguments of the critics within the banking industry. We develop a simulation model that captures the essential characteristics of a modern universal bank with investment banking and commercial banking activities that hedges its interest rate risks in the banking book through internal contracts with the trading book. We run simulations for our model bank following different banking strategies (fully hedged and partially hedged risks) using historical interest rates from periods with respectively rising and decreasing interest rates.

Our application of different sets of accounting rules - IAS before IAS 39 became effective the "Old IAS", "Current IAS or US GAAP", with and without hedge accounting under IAS 39 or SFAS 133 and the full fair value model of the JWG Draft Standard - to the activities of our model bank in the different interest rate scenarios, yields important insights. We start with Old IAS - the accounting model still preferred by the banking industry ${ }^{3}$ - and demonstrate that a fully hedged bank, that under our model assumptions has zero economic earnings, is in the position to adequately portray this in its financial statements. However, as Old IAS allows much discretion, a fully hedged bank 
may as well present income that is either positive or negative, for example, by not applying hedge accounting that is only optional under Old IAS.

We further show that under Current IAS or US GAAP, banks can not adequately portray their investment banking and commercial banking activities because of the restrictive hedge accounting rules, which do not allow best practice asset liability management activities to be adequately reflected in the financial statements.

We demonstrate that application of the mandatory full fair value model of the JWG Draft Standard bank adequately reflects the economics of the banking activities. The fully hedged bank has to present zero net income, if the bank hedges only part of its risks this will result in non-zero net income. The model does not allow discretion in presenting the results of the banking operations. This is the essential difference to the optional fair value model proposed by the International Accounting Standards Board (IASB) in the IAS 32 and IAS 39 Improvement Exposure Draft issued in June 2002. The latter does allow banks to adequately portray their business but does not require them to do so.

Our detailed analysis of the different sets of accounting rules, in addition, identifies critical issues of the different accounting models that have not been covered in previous accounting literature.

The paper proceeds as follows: In Section II. we describe the modelling of the activities of a modern universal bank with an asset liability management that maintains the preferred risk profile of the bank. We also describe the simplifying assumptions necessary to isolate the effects of the different accounting models. Sections III. to V. present and discuss the different accounting models: The banks' preferred "mixed model" developed under Old IAS, Current IAS rules (including IAS 39) and the JWG Full Fair Value Accounting model. The application of these rules yields different accounting results which are compared and discussed. Section VI. summarises the main conclusions and proposes areas for further research. 


\section{Modeling the Activities of a Modern Universal Bank}

\section{Characteristics of a Modern Universal Bank}

The distinguishing feature of a universal bank is its blend of commercial and investment banking activities. As a commercial bank, it serves as an intermediary between borrowers and lenders in the money and capital markets. The bank receives funds through current and savings accounts, term deposits and issued bonds and provides loans to its customers. As an investment bank, it advises and executes orders to buy and sell bonds, shares, currencies, and derivative products for its customers. Furthermore, large universal banks have trading units to offer their own investment banking products to their customers and to engage in trading on their own account.

Universal banks organise risk management according to the classical distinction of market price risk, credit risk, interest rate risk and liquidity risk. These risks are managed in specialised departments. Credit risk is usually managed in loan departments. Traditionally, they have pursued a "buy and hold" policy based on credit risk limits for individual counterparties, industry segments and geographical location. However, recent developments in the financial markets, in particular with respect to asset securitization and credit derivatives, enable banks to manage their loan portfolios and therefore their entire credit risk exposure more actively.

The market price risk and the liquidity risk of the trading book positions (i.e. trading positions of bonds, shares and derivatives) are managed by the trading departments. The currency, interest rate and liquidity risk of the banking book ${ }^{4}$ positions (i.e. loans and issued bonds) are managed by the asset liability management (ALM) so that the loan portfolio has only credit risk exposure. The ALM plays a central role in maintaining a transparent and managed interest rate and liquidity risk exposure of the entire bank. ${ }^{5}$

An example as displayed in Figure 1 shows how the ALM may become involved when external transactions occur. Consider a bank that currently maintains its desired risk exposure. This bank is now involved in two new customer-driven transactions. The first transaction is a loan of EUR 100 
million with a fixed rate of interest at 6 per cent annually and 5 years maturity. The second transaction is a 6 months deposit of EUR 50 million at 3.45 per cent. These two transactions add to the risk position of the bank in three dimensions. The loan implies additional (1) credit risk. As the deposit cannot match the loan in maturity or volume there is additional (2) liquidity risk and also additional (3) interest rate risk.

\section{[Insert Figure 1 about here]}

If the bank wants to re-establish its preferred - and previously held - risk position, it can issue a bond with a structure similar to that of the loan, buy interest rate swaps or sell interest rate futures. While an issued bond may hedge interest rate and liquidity risk, interest rate derivatives (i.e. swaps) hedge only interest rate risk but do not provide the liquidity (funding).

The ALM may hedge transactions on an individual basis so that the hedging instrument is directly linked to the hedged financial instrument ("micro hedges"). The ALM usually applies micro hedges only to large transactions with high market risk exposures, to transactions with embedded option components, and to transactions where accounting departments prescribe micro hedges in order to demonstrate particular hedge relationships. In general, however, the ALM manages risk at the portfolio level. The risk exposure can be expressed by risk factors for currency, interest rate, credit and liquidity risk.

In ALM banking practice, currency, interest rate and liquidity risk of a portfolio with deterministic cash flows is often analysed by the creation of time buckets for the aggregated cash flows of all transactions in the portfolio, usually distinguished by currencies. Based on the interest rate risk analysis of the portfolio, the ALM selects the hedging instruments with the appropriate volumes and maturities in order to maintain the desired risk exposure of the portfolio. In contrast to micro 
hedges, direct links between particular hedging instruments and hedged items are not the intent of portfolio hedges.

\section{Activities and Assumptions of the Model Bank}

We develop a model that captures the essential characteristics of a universal bank. In order to reduce the complexity of the model its focus is limited to interest rate products either belonging to the banking book or to the trading book and to the interest rate risk management. Other products and other risks can be included in extensions of the model.

The model bank can be described as a set of two portfolios, the banking book and the trading book. The portfolio of the banking book consists of loans, bonds, own bond issues, term deposits and interest rate swaps, while the portfolio of the trading book consists of bonds, interest rate swaps and term deposits. In order to optimise the bank's activities in the financial markets, interest rate swaps are only traded externally out of the trading book and internally between the trading book and the banking book. Term deposits, on the other hand, are only traded externally out of the banking book and internally between the banking book and the trading book. Bonds are directly bought into and sold out of both the banking and trading book.

Two banking strategies will be analysed. Under the first strategy, the bank is fully hedged against any movements of interest rates. Obviously, we expect no gains or losses from changing interest rates in the economic performance as well as in the financial accounting results under an appropriate set of accounting rules. Under the second strategy, the bank hedges only partially against changing interest rates. Here we expect gains or losses directly correlating to changing interest rates in the economic performance and financial accounting results. Under both strategies we apply micro hedges to reduce the interest rate risk from fixed rate assets to short term interest rate exposure. The short term interest rate exposure is hedged on a portfolio level by term deposits, which also provide the funding of the assets. 
The individual transactions of the model bank under both banking strategies are displayed in Table 1 for a scenario of decreasing interest rates using actual market data from the period 1994 to 1998. The same transactions are used under the scenario of increasing interest rates, however, with different interest rate coupons due to different market rates, again based on actual market data from the period 1987 to 1991 . The number of transactions for each product category is kept to a minimum so that the differences resulting from applying different sets of accounting rules can be more easily identified. For each transaction, the nominal volume is displayed in Table 1 together with the nominal rate of interest and the maturity in parentheses. All transactions are contracted at market rates; no product has a premium or discount.

[Insert Table 1 about here]

Our model bank is based on the following assumptions: ${ }^{6}$

(1) The bank maintains its original portfolio of assets and liabilities. It engages in no new transactions except for short term funding.

(2) The bank operates in an economy without regulatory capital and liquidity requirements, credit and liquidity risk.

(3) The bank operates at zero cost, pays no taxes and earns no fee or commission income.

Consider, for example, the hedges of the loans and bonds. Under the full hedge strategy the DEM 100 million fixed rate bond issue and a DEM 100 million interest rate payer-swap hedge the DEM 200 million fixed rate loan. Under the partial hedge strategy only the DEM 100 million fixed rate bond issue hedges the DEM 200 million fixed rate loan. The missing interest rate swap is the cause of the only open position in the partial hedge model. There is neither an internal swap between the banking book and the trading book (as hedge of the loan) nor a matching external swap in the 
trading book. The long position of the banking book thus translates into a long position of the bank. Since both internal and external swaps are missing in the hedge of the loan, the trading book remains in a fully hedged position in the partially hedged model bank. The bonds of both the trading and the banking book (with nominal volumes of DEM 100 million, DEM 50 million, and DEM 30 million) are hedged by corresponding interest rate swaps under both hedge strategies.

Assumptions $1-3$ imply that the economic performance of the model bank is completely determined by the cash flows of interest rate products. The model is applied to two actual interest rate periods in Germany, with rising interest rates from 1989 to 1991 and decreasing interest rates from 1996 to 1998 as displayed in Figure 2. In both periods the bank starts with the same set of transactions, which are built up in the two preceding years (1987/88 and 1994/95 respectively). We choose the interest rate swap curve as the standard valuation curve for each product. Application of the rates from the interest rate swap curves to the outstanding cash flows from the financial instruments yields the fair values of the financial instruments. ${ }^{7}$

[Insert Figure 2 about here]

In the absence of credit and liquidity risk (assumption 2) there are no fair value measurement problems to be addressed. The performance of each financial instrument $i$ in year $t^{*}\left(\operatorname{PFI}_{i, t^{*}}\right)$ is calculated as follows: 


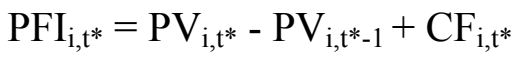

where $\quad \mathrm{PV}_{\mathrm{i}, \mathrm{t}^{*}}=$ Sum of discounted future cash flows $\mathrm{CF}_{\mathrm{i}, \mathrm{t}}$, for years $\mathrm{t}^{*+1}$ to maturity $\mathrm{m}$

$\left(\mathrm{t}=0, \ldots, \mathrm{m} ; 0<\mathrm{t}^{*}<\mathrm{m}\right)$, with discount factors derived from the yield curve at year $\mathrm{t}^{*}$

$\mathrm{CF}_{\mathrm{i}, \mathrm{t}^{*}}=$ Cash flow of financial instrument $\mathrm{i}$ in year $\mathrm{t}^{*}$

The model bank has a performance of zero in all accounting periods when it is fully hedged. This is the benchmark result that should be displayed in the financial statements. In the case of the partial hedge, the long position of the model bank book leads to a negative (positive) performance for rising (decreasing) rates of interest, while the trading book still has a performance of zero. Thus, we expect negative (positive) net interest income and net income for rising (decreasing) interest rates also in the financial statements. 


\section{Accounting under IAS before Effectiveness of IAS 39 ("Old IAS")}

Since the mid 1990's most German and Swiss private banks have started to publish IAS group accounts. We discuss IAS rules for financial instruments before IAS 39 became effective in 2000 because this is the "mixed model" still preferred by the banking industry. ${ }^{8}$

\section{Accounting Rules for Financial Instruments under Old IAS}

Under Old IAS all financial assets are initially recognised at historical cost. For subsequent measurement of current investments IAS 25 offered a choice between lower of cost or market, mark to market and portfolio accounting. For long-term investments, valuation could have been at amortised cost, at revalued amounts, or at lower of cost or market. Amortised cost measurement was applied to all liabilities without an explicit standard. ${ }^{9}$

In the absence of explicit rules the banking industry developed a "best industry practice" that is not documented in detail in either the academic or in the professional literature. This practice is based on the distinction of trading activities and banking (book) activities. Fair value measurement is applied to all trading book assets and liabilities including derivative instruments with all changes in fair value recognised immediately in net income. ${ }^{10}$ All banking book financial assets and liabilities are measured on an amortised cost basis. Derivative instruments in the banking book are not recognised as assets or liabilities but treated as "off-balance sheet" contracts that may require making provisions for losses from unperformed contracts.

The first anomaly of these measurement rules is that identical financial instruments are reported differently depending on their allocation either to the trading book or to the banking book. If, for example, a bank purchases government bonds and allocates them in part to trading and in part to banking book activities, increases in fair value due to declining interest rates will only be included in the valuation of the trading book assets. 
We demonstrate further implications of Old IAS as interpreted by banks using examples of fixed rate assets and liabilities hedged by interest rate swaps with identical interest rates and maturities in Table 2. In the trading book both the change in fair value of the assets and of the swap are recognised in net income (“compensating valuation"). The offset will be perfect for perfect hedges; for imperfect hedges any inefficiencies caused, for example, by different notional amounts or maturities or different counterparty risks of assets and swaps, will show up in net income. Special hedge accounting rules are not required to reflect the economics.

[Insert Table 2 about here]

Changes in the fair value of loans and liabilities of the banking book due to rising or falling interest rates are not recognized in net income under Old IAS. However, interest rate swaps might have a negative fair value (with rising rates for receiver swaps and falling rates for payer swaps) requiring the setting up of a provision for unrealised losses from unperformed contracts. Thus, we observe mismatches in earnings for fully hedged fixed rate loans with declining interest rates or for fully hedged fixed rate liabilities with increasing interest rates.

With rising interest rates fixed rate securities in the banking book must be written down to lower market value ${ }^{11}$, whereas unrealised gains on the hedging derivatives may not be recognised in net income under Old IAS rules without hedge accounting. This results in an earnings mismatch for a fully hedged banking book position of investment securities for both rising and declining interest rates.

In an attempt to overcome the earnings mismatches identified above, banks interpret Old IAS rules as being open to an "off-balance sheet" hedging approach. Under this approach, banking book derivative instruments are again not recognised as assets or liabilities. When designated as hedging 
instruments, derivatives remain unvalued if the hedged items are measured at cost (e.g. loans or receivables). This implies that there are no provisions for losses from negative fair values of derivative hedging instruments. This corresponding non-valuation - or better said: compensating misevaluation - assumes the existence of a perfect hedge where changes in fair value of both the hedged item and the hedging instrument fully offset each other. Therefore, the approach does not display hedge inefficiencies that result from differences in the changes of fair value of loans or liabilities and swaps.

Where a derivative instrument hedges an investment security in the banking book, hedge inefficiencies in part show up in net income. The banking book derivative is not recognised, except for an overhang of losses, which require the setting up of a provision. An overhang of unrealised gains remains unconsidered (“zero line approach"). ${ }^{12}$

Hedging inefficiencies have been largely accepted if they were caused by changes of interest rate curves belonging to different market segments (i.e. interest rate swaps and bonds). They have been less accepted if the hedge inefficiency was caused by maturity gaps (e.g., if a bond with a maturity of 12 years is hedged by a bond future whose underlying cheapest to deliver bond has a maturity of 8 years). Cross currency hedges of weakly correlated currencies were not accepted.

Banks have interpreted Old IAS as allowing macro hedge accounting. In a macro hedge a portfolio of banking book assets and liabilities is defined as a hedged item. Unlike micro hedging, this can also involve more than one hedging instrument or hedged item, macro hedging proceeds on in a dynamic way. This means that the hedging derivatives are adjusted with any new transaction (e.g. prolongation of a loan). Risk management techniques permit the measurement of interest rate risk (e.g. by basis point values) and demonstrate that hedging reduces the risk exposure. If a banking book portfolio is managed with a near to zero risk limit (working balance) macro hedge accounting in banks has been widely considered to be an acceptable interpretation of Old IAS. 
As outlined in Section II.1. modern universal banks often manage risks in the banking book using internal derivative contracts. In Table 3 the banking book consists of a fixed rate loan financed by a variable rate term deposit. To hedge the open interest rate position the treasury department enters into an internal swap with the trading desk paying fixed interest rate payments over the term of the loan. The trading desk enters into an offsetting swap with a third-party who receives the fixed rate.

[Insert Table 3 about here]

Internal derivatives do not qualify as assets or liabilities. Therefore, positive and negative fair values and changes in fair values from internal derivatives have to be eliminated upon consolidation. Even though the positions of the trading book and the banking book fully hedge each other, the bank will have to show a positive trading income with rising interest rates and a negative trading income with falling interest rates. In the banking book rising interest rates will lead to higher interest expenses for the term deposit, resulting in a lower (net) interest income as the offsetting earnings effect of the internal swap is not taken into account.

In the trading book the positive fair valuation effect of the payer swap, comprising the present value of all future fixed rate swap payments, is recognised in net trading income immediately in the period of rising interest rates. The compensating effect of lower net interest income in the banking book shows up only over the term of the hedge. Thus, net income of the bank becomes volatile even though economically the bank faces no interest rate risk.

This mismatch in accounting earnings has been overcome by another interpretation of Old IAS that allows to treat internal transactions like external ones if contracted at arms' length and valued under the same assumptions as external deals. ${ }^{13}$ However, this leads to a second anomaly in the Old IAS accounting as the trading book side of the derivative contract is marked at fair value while the 
banking book side remains unvalued or in the case of securities, the measurement results are compensated off-balance sheet under the zero line approach as described above. The differing measurements of the internal derivatives in the trading book and in the banking book then require the entry of a balancing item ("plug") under the assets or liabilities - a peculiarity forced by the logic of double entry book keeping.

It could be argued that banks should designate the external deal in the trading book as a (micro) hedge of the banking book loan. This would work in simple settings and also in our simplified banking model. Under dynamic ALM hedges using internal derivatives with the market maker in the trading book it is often impossible to document the link.

\section{Application of Old IAS to the Model Bank}

Table 4 Panel A presents the results of applying Old IAS to our fully hedged model bank. In the scenario of declining interest rates the fair values of the fixed rate assets and liabilities increase. ${ }^{14}$ The risk in the banking book resulting from a long position in fixed rate assets is hedged via an internal derivative with the trading book. The open position from the internal contract in the trading book is closed by an external swap in the market.

[Insert Table 4 about here]

The model bank has "natural hedges"; of trading book securities carried at fair value and hedged by trading book derivatives carried at fair value ("compensating valuation"); and of banking book fixed rate assets and liabilities both carried at cost ("compensating misevaluation"). From increases in the fair value of loans (1996: 112.27-100.00 = 12.27) and the fair value of investment securities (1996: 88.53-80.00 $=8.53$, the net long position in banking book fixed rate assets results in an unrecognized gain (1996: 20.80). The corresponding loss on the external derivative hedging 
instrument of the banking book (1996: -20.80) is recognized in net income. Without hedge accounting under Old IAS the fully hedged model bank would present negative net income in the scenario of declining interest rates. Here hedge accounting under Old IAS requires inserting a "plug" asset (1996: 20.80) created by credits to net income in order to arrive at the fully hedged bank presenting zero net income and to adequately portray the economic situation.

The "plug" asset (or with increasing interest rates the "plug" liability) is a very interesting item as it represents the net change in fair value of the banking book assets and/or liabilities and attributable to the risk that has been hedged via internal contracts with the trading book. ${ }^{15}$ If the model bank does not hedge the interest rate risk from the long fixed rate position in the banking book there would be no necessity for a "plug" asset or liability. Table 5 Panel A demonstrates this for the partial hedge strategy where the long position in loans (100) remains unhedged and the amount of the "plug" asset decreases correspondingly (1996: 8.53).

German banks appear to handle the "plug" items as a technical issue presumably viewed as immaterial in most cases and probably therefore not disclosed separately in financial statements. Reviewing the 2000 fiscal year end annual reports we found no bank disclosing or explaining such an item in the notes to financial statements.

[Insert Table 5 about here]

Under the partial hedge strategy in Table 5 Panel A, the model bank does not close the long position in fixed rate assets in the market and thus shows positive net interest income (1996: 4.28) with decreasing interest rates because of the reduced variable interest cost to refinance. There is no effect on trading income because we assume that the trading department in our model bank closes all risks from traded securities and the internal derivative hedging of the investment securities in the market. 
We further assume that the model bank sells part of the investment securities portfolio (50.00) at the end of 1997 at the current market price (53.04) and immediately buys the securities back at the same price. The sale results in a realized gain (3.04) in the scenario of decreasing interest rates. The question arises whether the corresponding (unrealized) loss (-3.04) on the internal hedging instrument should be included in net income from investments.

Risk management has no reason for closing out the internal hedge and thus realizing the loss on the internal contract, as the risk position is virtually unchanged. For Old IAS we argue that selling or closing out hedged items should be accompanied with recognizing the compensating gain or loss on the hedging derivative in net income from investments, even if the risk position does not change as in our example. Else there would be an incentive for earnings management ("cherry picking").

However, identifying the compensating gain or loss of the hedging instrument is realistic only with micro hedges. For a bank following dynamic macro hedging strategies there is often no possibility to identify a single hedging derivative that must be closed out upon sale of a security. A similar problem arises when hedging derivatives are terminated before maturity of the hedged item. The argument for the matching principle interpretations of Old IAS is that with micro hedging, the recognition of close out payments in net income is not immediate but is spread over the remaining term of the hedged item. ${ }^{16}$ This implies that realised gains have to be included under liabilities and realised losses under assets - another strange implication of Old IAS "best industry practice". In a macro hedge environment there is again no clear solution to the problem of how to allocate close out payments to hedged items with a defined maturity.

To summarise, for a fully hedged bank the interpretations of Old IAS enable the presentation of zero net income and thus to present the economic results in an adequate manner. As the banking book assets and liabilities are carried at cost fair value changes are not directly recognized but the hedged part shows up in the "plug" under other assets or other liabilities. Fair value changes of fixed rate banking book assets and liabilities that form "natural hedges" show up neither in the balance sheet 
nor in the income statement ("compensating misevaluation") and thus do not display any existing inefficiencies of the hedges. As hedge accounting under Old IAS is optional, companies may choose not to present the economics of their hedging strategy in such a manner. However, banks typically have chosen the hedge accounting option at least in part.

For partial hedging strategies only part of the fair value changes attributable to the risk being hedged shows up in the "plug" asset or liability. Changes in the fair value of unhedged banking book assets and liabilities are not fully recognised in the period of the interest rate change but show up in net income over the remaining term of the instruments under Old IAS. Thus, net income effects of running open positions in the banking book are spread over the following periods. 


\section{Accounting under Current IAS and US GAAP}

As part of its comprehensive project on the accounting for financial instruments, the FASB issued SFAS 115 requiring a fair valuation for certain investments in securities and SFAS 133 requiring that all derivative financial instruments be marked to fair value. SFAS 133 also introduces explicit rules for hedge accounting. IAS 39 closely follows the US rules. In the following sections we parallel both IAS and US GAAP. We will start with a discussion of current rules without hedge accounting, as the requirements for hedge accounting in IAS 39 and SFAS 133 are burdensome and may be most difficult to comply with for banks following best practice risk management, which is based on macro hedging.

\section{Accounting Rules for Financial Instruments under Current IAS and US GAAP}

Although the Current IAS or US GAAP standards increase the use of fair values for financial instruments we still have a mixed model. Fair value measurement applies to financial assets and financial liabilities of the trading portfolio with all changes in fair value to be included in net income.

Fair value measurement also applies to available for sale financial assets. For income recognition of gains and losses from available for sale financial assets, an enterprise may choose, under IAS $39.103 \mathrm{~b}$ only, between; the immediate recognition in net income and presentation in other comprehensive income (OCI) with a recycling to net income in the following periods. Most banks choose the second option, which is the only one permitted under US GAAP. Loans originated by the bank, held to maturity investments, and all non-trading liabilities continue to be measured at amortised cost. Under Current IAS and US GAAP, originated loans and held to maturity securities require an impairment test. However, both Current IAS and US GAAP do not allow the writing down of such assets to lower fair value as a consequence of increasing market interest rates. Impairments only consider the probability of non-collectibles in respect of all payments (interest, principal) due under the contractual terms. Further, both Current IAS and US GAAP prescribe using 
the effective interest rate method to determine the present value of expected future cash flows and thus avoid measurement at fair value. ${ }^{17}$

Under Current IAS and US GAAP all derivative instruments are considered to be rights or obligations that meet the definition of assets or liabilities. ${ }^{18}$ All derivatives are to be measured at fair value with changes in fair value recognised in net income with the exception of derivative instruments designated as hedging instruments in cash flow hedges, where changes are recognised in other comprehensive income.

Under these rules earnings mismatches occur because the banking book assets and liabilities and the related hedging derivative instruments are measured differently. Whereas all derivatives are measured at fair value with changes being immediately reflected in net income originated loans, held to maturity investments and non-trading liabilities are measured at cost, with the effect of changes in interest rates only being shown in net income over time. For available for sale assets, a mismatch may also arise between net income and other comprehensive income. For "natural" hedges in the banking book between balance sheet items measured at cost (e.g. a fixed rate loan and a fixed rate liability with the same notional amount and maturity) the compensating misevaluation creates no mismatch in earnings. However, any inefficiencies of natural hedges of banking book assets and liabilities will not show up in earnings in the periods of changing interest rates, but only over the remaining term of the instruments.

\section{Application of Current IAS and US GAAP without Hedge Accounting}

For our model bank, we allocate investment securities in part to the category "available for sale" (50.00) and "held to maturity" (30.00). We apply the option in IAS 39.103b and show all changes in fair value in other comprehensive income. Banking book loans are classified as "originated by the enterprise". All derivatives are measured at fair value with changes in fair value to be included in net income as here we do not apply the hedge accounting options offered by IAS 39 or SFAS 133. 
Table 4 Panel B shows the results of a fully hedged bank in the scenario of declining interest rates. The change in fair value of fixed rate loans (1996: 24.54) and of the held to maturity securities (1996: 3.82) as well as the corresponding loss on the issued bonds (1996: -12.27) forming partially a natural hedge are again not recognised ("compensating misevaluation"). The related hedging derivatives are measured at fair value with the decline in fair value recognized in net income (1996: $-12.27-3.83=-16.10)$. They are displayed as trading liabilities together with the fair value of the hedge of the trading book assets and the hedge of available for sale securities (1996: -16.102.37-4.70 = -23.17). Even though all banking book assets and liabilities are fully hedged, Current IAS require a bank not applying hedge accounting to present non zero accounting income because of the different measurement rules for hedged items and derivative hedging instruments.

Available for sale securities are hedged via internal derivatives with external swaps in the trading book. With decreasing interest rates, the gain from increasing fair values of available for sale securities is allocated to other comprehensive income (1996: 4.70). The change in fair value of the external hedging derivative is negative (1996: -4.70) and recognized in net trading income. Thus, we observe a mismatch between net income and other comprehensive income.

Upon sale of the available for sale securities in 1997 , the gain realized (3.04) ${ }^{19}$ is reallocated from other comprehensive income to net income. This possibility of recycling gains (or losses in a scenario of increasing interest rates) allows some discretion for net income management under the current rules.

For the fully hedged bank we observe in Table 5 Panel B, negative net income (1996: -1.96) with decreasing interest rates. Net interest income is positive $(1996:+7.47)$ and results from the interest payments on the banking book assets and liabilities and also from the interest allocated to the refinancing of the trading book. ${ }^{20}$ Net trading income measured on a fair value basis is negative (1996: -9.43). Thus, the non-zero net income (1996: -1.96) is due to the different measurement bases for the banking book (accrual accounting) and for the trading book (fair value accounting). 
The results for the partial hedging strategy under Current IAS or US GAAP without hedge accounting are presented in Table 5 Panel B. Net income is positive in the scenario of decreasing interest rates (1996: 3.87) as expected. Compared to the fully hedged strategy the net interest income (1996: 7.54) is nearly unchanged because the net interest payments on banking book assets are the same except for the liabilities to banks. Users of accounting information are therefore no longer able to derive information on maturity transformation from the income statement, as both a fully hedged bank and a bank with a partially hedged banking book present non zero net interest income.

The trading component of net income is less volatile for the model bank under the partial hedging strategy than under the fully hedged strategy. The net long position of the trading book is reduced because of the amount of external swaps hedging the banking book assets is smaller and thus net trading income is reduced. The volatility of net trading income can be further reduced or even eliminated if external swaps are entered into only for hedges of trading book assets. For our model bank this would mean not to hedge available for sale and held to maturity securities. Thus, Current IAS rules may discourage economically sensible hedges for which hedge accounting is either not accepted or not practical. As banks cannot leave the banking book completely unhedged they have to look for hedge accounting options that can be applied to their existing strategies or for amendments to their strategies.

\section{Fair Value Hedge Accounting under Current IAS and US GAAP}

IAS 39 and SFAS 133 offer two basic forms of hedge accounting - fair value hedge accounting and cash flow hedge accounting - if certain qualification criteria are met. Fair value hedge accounting can be applied to the exposure of changes in fair value of a recognised asset or liability, or - only under US GAAP - a firm commitment. For example, a USD denominated Argentina government bond can be hedged with a total return swap covering all risk categories involved. Alternatively, each single risk factor (e.g. benchmark interest rate, counterparty risk, foreign currency risk) can be 
hedged with a suitable derivative. Held to maturity assets may not be designated as hedged items in a hedge of interest rate changes (IAS 39.127; SFAS 133.21d).

A bank may designate its interest risk management activities either as a fair value hedge or as a cash flow hedge. ${ }^{21}$ In Table 6 we look at a fixed rate financial asset refinanced by variable rate term deposits, which are assumed to roll over until maturity of the funded asset. The interest rate risk is effectively hedged by an interest rate swap under which the bank pays fixed rate interest and receives the variable rate. The combination of the fixed rate financial asset and the swap creates a synthetic variable rate financial asset whose fair value does not change with changes in interest rates.

[Insert Table 6 about here]

Under fair value hedge accounting all changes in the fair value of a derivative hedging instrument are recognised in net income. The carrying amount of a hedged item in a fair value hedge is adjusted for its change in fair value, attributable to the risk being hedged ("basis adjustment"). Internal derivatives may not be designated as hedging instruments under both Current IAS or US GAAP as they have to be eliminated upon consolidation. As an exception they can be designated as hedging instruments for interest rate risk only if they are directly offset by third party contracts ${ }^{22}$. Thus fair value hedge accounting can avoid earnings mismatches in the banking book if, and only if, the link between the hedged loan and external hedge derivatives can be demonstrated. This requirement causes a lot of trouble for practical application in a modern bank risk management environment where dynamic macro hedging strategies are followed. ${ }^{23}$ 
Table 4 Panel $\mathrm{C}$ presents fair value hedge accounting with decreasing interest rates. For our fully hedged model bank it is easy to fulfill the burdensome documentation and effectiveness requirements of IAS 39 or SFAS 133 as we can identify almost perfect micro hedge relationships. Since the model bank has economically hedged held to maturity financial assets, the current rules in IAS 39 or SFAS 133 again create a mismatch in net income. The fair value change of the derivative hedging instrument is recognised in net income (1996: -3.82), whereas the fair value change of the held to maturity securities does not appear either in the balance sheet or in net income.

Our model bank hedges the loans with issued bonds and with swaps. The natural hedge of the loan and the issued bond both carried at cost does not appear either in the balance sheet or in the income statement ("compensating misevaluation"). The change in fair value of the external swap hedging the remaining interest rate risk of the loans (1996: -12.27) is recognised and displayed under hedging derivatives, together with the swap hedging the available for sale securities (1996: -4.70). The internal swaps economically hedging the long position in loans are treated as non-existent in the financial statements as they are eliminated upon consolidation. However, internal contracts are useful to document the link between the hedged items in the banking book and the hedging instrument in the trading book.

The offset in net income is achieved for the loans by a fair value basis adjustment of the carrying amount of the hedged item. This basis adjustment $(1996: 200.00+12.27=212.27)$ allocates the "plug" to the carrying amount of the hedged item carried at cost. ${ }^{24}$

Available for sale securities are measured at fair value with the change in fair value (1996: 4.70) recognised in other comprehensive income. Upon designation of a fair value hedge, changes in fair value of available for sale securities have to be recognised in net income (IAS 39.153b; SFAS 133.22b) in order to offset the corresponding changes in fair value of the derivative hedging instrument. 
Thus, we find the "plug" asset of 20.80 identified under the same scenario under Old IAS as an allocation to net income for the held to maturity securities that do not qualify for IAS 39 hedge accounting (3.83), as a basis adjustment to the carrying value of the loan (12.27) and as a fair value adjustment of the available for sale securities (4.70).

In the income statement we find a non zero net interest income (1996: 1.29) and a non zero net trading income (1996: -1.75) for our fully hedged bank that uses all available possibilities of fair value hedge accounting offered by IAS 39 or SFAS 133. The combined effect on net income (1996: -0.47) represents the fair value change of the external hedging swap, which has no contra entry, because the hedged held to maturity security is valued at cost.

Table 5 Panel C presents the results of applying IAS 39 or SFAS 133 fair value hedge accounting to a partially hedged bank. Only available for sale securities are hedged by qualifying derivative hedging instruments (1996: -4.70). Unhedged loans and held to maturity securities, are carried at cost. As expected for a partially hedged bank we observe non zero net income (1996: 3.81). As the position has been taken in the banking book by not hedging the loans we find as expected, a non zero net interest income (1996: 5.57). This is the result of interest earned on the held to maturity securities (1996: 2.37) being financed by variable rate deposits (1996: -1.08) and of the positive interest margin due to interest earned on the loan (7.89) that is also financed by variable rate deposits $(-3.61)$.

\section{Cash Flow Hedge Accounting under Current IAS and US GAAP}

Cash flow hedge accounting may be applied to hedges that offset the variability of cash flows, which are attributable to a particular risk associated with a recognized asset or liability, an unrecognized firm commitment or a forecasted transaction. IAS 39.137 also applies cash flow hedge accounting to hedges of unrecognized firm commitments even though they have a fair value exposure. Under cash flow hedge accounting the change in fair value of the derivative hedging 
instrument attributable to the hedged risk is included in other comprehensive income and "recycled" to net income at the time when the hedged transaction affects earnings. ${ }^{25}$

The concept of cash flow hedge accounting is demonstrated in Table 6 above using the same hedged items and derivative hedging instruments as in the fair value hedge. Under cash flow hedge accounting, the variable interest received on the payer swap is thought to offset the variable interest expenses on the term deposits and thus eliminates the exposure to changes in future interest cash flows. This is based on the assumption that the variable rate term deposits are rolled over and can be interpreted as highly probable forecasted transactions. ${ }^{26}$

Table 4 Panel D demonstrates the results of applying cash flow hedge accounting to all hedges of our model bank. Assets and liabilities are carried either at cost or at fair value as already explained in Section IV.2 for the situation without hedge accounting under Current IAS. With cash flow hedge accounting there are no (basis) adjustments to the carrying amounts of the hedged items.

IAS 39.127 prohibits the designation of held to maturity financial assets as hedged items in a cash flow hedge. However, according to IGC QA 127-4 it is accepted to "hedge the exposure to cash flow risk associated with the forecasted future interest receipts on debt instruments resulting from the reinvestment of interest receipts on a fixed rate asset classified as held to maturity". This strange line of argument accepts cash flow hedge accounting also for held to maturity investments.

Derivative hedging instruments are carried at fair value and displayed in Table 4 Panel D separately, as trading liabilities (1996: 2.37) and as hedge derivatives of the variable refinancing of the banking book (1996: 20.80). These instruments are comprised of the swaps hedging available for sale securities (-4.70), held to maturity securities (-3.82) and loans (-12.27). All changes in fair value of the swaps designated as cash flow hedging instruments are included in other comprehensive income. There is an offsetting change in fair value of available for sale securities (1996: 4.70). In the absence of detailed presentation rules, we strongly recommend that these components of other comprehensive income should be disclosed as separate line items in the statement of changes in 
equity. There is no offset for the changes in fair value of the swaps hedging the variable rate refinancing of the loans and held to maturity securities included in prior periods and current period other comprehensive income $(1996:-3.82-12.27=-16.09)$. Thus, the mismatch due to the fair value measurement of the swaps and the cost basis of the hedged items appears as a "plug" in other comprehensive income.

In Table 4 Panel $\mathrm{D}$ we find zero net income and also zero net interest income and zero trading income under Current IAS or US GAAP, with cash flow accounting as expected for a fully hedged bank. The volatility in net income is completely removed if all hedges can be and are designated as cash flow hedges. However, we observe volatility in other comprehensive income and thus volatility in equity.

If we compare comprehensive income under Current IAS or US GAAP without hedge accounting (Table 4 Panel B) with comprehensive income under Current IAS with all hedges designated as cash flow hedges (Table 4 Panel D), we see that both bottom lines are identical. The volatility that shows up in net income if no hedge accounting is applied is now completely removed and transferred to other comprehensive income. By choosing the level of (optional) cash flow hedge accounting a bank can influence the allocations to net income or to other comprehensive income.

To summarise, cash flow hedge accounting reallocates the mismatches resulting from different measurements of hedged items and hedging instruments to other comprehensive income. The resulting volatility of equity is a serious disadvantage. The equity base of a bank changes although, from an economic point of view there is no volatility. This is difficult to explain to users of financial statements. Nevertheless, cash flow hedge accounting remains an alternative chosen by a number of banks because it might be easier to demonstrate the required hedge effectiveness. ${ }^{27}$ 


\section{Accounting under a Full Fair Value Model}

Current IAS and US GAAP rules for financial instruments have been labelled interim solutions that should be overcome by a comprehensive standard of accounting for all financial instruments as soon as possible. The debate on a comprehensive standard has been intensive and controversial. In December 2000 the JWG issued a Draft Standard proposing a mandatory full fair value model of accounting for all financial instruments. The JWG Draft Standard has been heavily criticized, in particular, by representatives from the banking industry for not adequately mirroring the economics of the banking business.

\section{Accounting under the JWG Mandatory Full Fair Value Model}

For measurement purposes the JWG in principle does not distinguish between different types of financial instruments but applies fair value measurement to all financial assets and all financial liabilities included in the scope of the Draft Standard. All gains and losses resulting from changes in fair value are to be recognised in net income in the period in which the change in fair value arises. An exception is made for certain foreign currency translation gains and losses, which have to be presented separately as a change in equity according to IAS 21.30 or SFAS $52.13 .^{28}$

For presentation purposes the JWG Draft Standard requires separate disclosure of certain financial assets and financial liabilities on the face of the balance sheet or in the notes to the financial statements.

The JWG Draft Standard in particular does not permit special hedge accounting for financial instruments even if they are specifically entered into for purposes of risk management. All gains and losses from changes in fair value of hedging financial instruments are to be included in net income just as for any other financial instrument. Additional disclosures are required on the objectives and policies of risk management and on the financial risk position. Gains or losses on financial instruments hedging anticipated transactions in future reporting periods may be separately disclosed 
in the income statement together with a detailed description of the risk management strategies followed. ${ }^{29}$ For the presentation of interest revenues and expenses in the income statement, the JWG Draft Standard requires application of the concept of fair value interest to be calculated using the current yield to maturity or the yield curve of current market forward rates. ${ }^{30}$

All financial instruments - including all derivative instruments - of our model bank fall within the scope of the JWG Draft Standard and therefore are measured at fair value with all changes in fair value to be included in net income. Thus, we do not have a mixed model for financial instruments that causes earnings mismatches. ${ }^{31}$ Our presentations of results do not apply the presentation rules of the JWG Draft Standard but retain the balance sheet and income statement classification of Current IAS or US GAAP in order to clearly demonstrate the differences.

Table 4 Panel E presents the results for the fully hedged bank in the scenario of decreasing interest rates. The model bank shows as expected zero net income in each period. Separate disclosure of gains or losses from the sale and repurchase of available for sale securities is not necessary as net income under a full fair value model is not affected by the decisions to hold or sell a financial instrument.

All financial assets and liabilities of the trading book and of the banking book are presented at fair value in the balance sheet reflecting all changes in market interest rates immediately. There is no need for the presentation of "plug" assets or liabilities as under Old IAS or "plug" basis adjustments to the carrying amounts of hedged items or "plugs" in other comprehensive income as under Current IAS or US GAAP. There are no hedge accounting artifacts.

For the partially hedged bank Table 5 Panel E demonstrates positive net income (1996: 5.83) in the scenario of decreasing interest rates as it is to be expected from the unhedged long position in fixed rate loans. As the model bank takes the position in the banking book is shown the result under net interest income. Any change in market interest rates will show up immediately in the fair valuation and thus in net income. Consequently, a successful or a failed maturity transformation becomes 
transparent immediately and not as under Old IAS (Table 5 Panel A) only over the remaining terms of the financial instruments.

\section{Accounting under the IAS 39 Improvement Proposal of an Optional Fair Value Model}

In June 2002 the IASB issued an IAS 32 and IAS 39 Improvement Exposure Draft proposing an optional fair value model. At initial application of an amended standard companies may designate financial assets (e.g. loans originated by the enterprise) and financial liabilities (e.g. issued bonds) previously not classified as trading for measurement at fair value. Financial instruments designated to this new category should be presented separately for example as "financial instruments at fair value (through net income)". ${ }^{32}$ After initial application of the amendment, designation for fair value accounting is only allowed at initial recognition of financial assets and liabilities. A financial instrument should not be reclassified into or out of the trading category. ${ }^{33}$

This optional fair value model allows to overcome some of the anomalies resulting from different measurement methods, as the natural offset of fair value changes eliminates the need for burdensome hedge accounting documentation. According to the basis for conclusions the IASB does not intend "to force entities to measure more financial instruments at fair value". For banks designating all financial instruments that are included in portfolios hedged via macro hedging strategies, the amendment offers a way out of the current hedge accounting problems.

The optional fair value model will not make comparisons between enterprises easier. A bank that runs open positions in the banking book with financial instruments carried at cost may temporarily not be distinguishable from a fully hedged bank. However, this critique applies equally to Old IAS and Current IAS and US GAAP where hedge accounting is optional. Adding another option that allow banks to adequately portray their macro hedging activities is in our view an improvement if accompanied by sufficient disclosures or the risk management and the accounting choices. 


\section{Conclusions}

The application of different sets of accounting rules for financial instruments to the model bank provides important insights. We demonstrate that only under Old IAS or under a full fair value model we can arrive at financial statements that adequately portray the economic (zero) results of a fully hedged bank

However, under Old IAS this result is only achieved by entering "plug" assets or liabilities created by debits or credits to net income which are not compatible with the definitions of assets and liabilities either in the IAS Framework or in the FASB Concepts Statements. They are hedge accounting artifacts.

Under Old IAS banks may choose whether to adequately portray their activities or not. For the fully hedged model bank this means that we can arrive at zero net income for all periods but we also can produce non zero accounting results by not applying hedge accounting to all economic hedges. Conversely, zero net income does not imply that a bank is fully hedged under Old IAS. If a bank runs open positions in fixed rate financial assets and liabilities carried at cost, changes in fair value will not affect net income under Old IAS.

The Old IAS mixed model is still the preferred model of the banking industry arguing that this model allows an adequate presentation of banking activities. The major problems with the Old IAS mixed model are the conceptual problems of the hedge accounting approach and its optionality, offering ample opportunities for creative accounting.

Current IAS and US GAAP appear to be even worse. We demonstrate that a fully hedged bank cannot present zero net income even if all possibilities of fair value hedge accounting are used. Under IAS 39 or SFAS 133 fair value hedge accounting, the "plugs" identified before are not recognised as assets or liabilities but included as basis adjustments in the carrying amounts of the hedged items. Thus, we have strange valuations of hedged items that are neither cost nor market but again hedge accounting artifacts. Using cash flow hedge accounting banks can remove the volatility 
from net income but not from comprehensive income. A fully hedged bank will have to present changes in equity with changing interest rates - a result not easily explainable to users of financial statements.

The key problem of modern universal banks following dynamic macro hedging techniques is the narrow micro hedging concept implied in IAS 39 and SFAS 133. Banks often are not able or willing to fulfill these burdensome documentation requirements and therefore opt not to choose hedge accounting for all hedging activities. Thus, a fully hedged bank might present more volatile net income than a partially hedged bank, as demonstrated by our model results. As a consequence, financial statements of banks are hardly comparable for users under Current IAS or US GAAP.

Application of the mandatory full fair value model proposed in the JWG Draft Standard results in financial statements adequately portraying the economic activities of the model bank. Changes in interest rates affect the (fair) values of all fixed rate financial instruments, derivative instruments and net income as well as equity immediately and fully in the period of the rate change and are not spread over subsequent periods. There is no need to introduce hedge accounting artifacts like "plug" assets or liabilities or basis adjustments.

The mandatory full fair value model offers no choices in the preparation of accounts and results in financial statements that are easier to compare. Certainly, there are additional problems to overcome when extending fair value measurements to more classes of financial assets and liabilities (e.g. fair value measurement problems ${ }^{34}$ ). These problems then need to be addressed and resolved. This is in our opinion the most promising way ahead, out of the unsatisfactory current situation. The banking industry "argument" that a full fair value model does not adequately portray the economics of the banking business has been discarded by the results of our analysis.

The optional fair value model proposed by the IASB in the recent IAS 32 and 39 Improvement Exposure Draft may be a useful interim solution providing the option to gain experience with an extended use of fair values in bank accounting. 


\section{References}

Bessis, J., (2002) Risk Management in Banking, $2^{\text {nd }}$ edition, Chichester: John Wiley and Sons.

Breker, N., Gebhardt G., Pape J. (2000) 'Das Fair-Value-Projekt für Finanzinstrumente - Stand der Erörterungen der Joint Working Group of Standard Setters im Juli 2000', Die Wirtschaftsprüfung, 53(16): 729-744.

Bundesverband deutscher Banken (2001) 'Bilanzierung von Sicherungsgeschäften (Hedge Accounting) nach IAS 39', Die Wirtschaftsprüfung, 54(6): 346-353.

Fédération Bancaire de l'Union Européenne (FBE) (2003) 'Macro Hedging of Interest Risk', April 2003 (http://www. fbe.be/documents.html).

Gebhardt, G. (2000) 'Risikomanagement und Rechnungslegung - ein Kernproblem in der Diskussion zur Bilanzierung von Finanzinstrumenten', ZfbF-Sonderheft, 45: 69-94.

Gebhardt, G., Reichardt, R., Wittenbrink, C. (2002) 'Accounting for Financial Instruments in the Banking Industry', Working Paper Series: Finance \& Accounting, Goethe-University Frankfurt, No. 95, November 2002 (http://www.wiwi.uni-frankfurt.de/professoren/gebhardt/public.php).

Joint Working Group of Standard Setters (JWG) (1999) 'Financial Instruments - Issues Relating to Banks', August 1999 (http://www.iasc.org.uk/docs/fijwg/banksjwg.pdf).

Joint Working Group of Standard Setters (JWG) (2000) Financial Instruments and Similar Items, London: International Accounting Standards Committee.

Joint Working Group of Banking Associations on Financial Instruments (1999) 'Accounting for Financial Instruments for Banks', October 1999 (http://www.iasc.org.uk/docs/fijwg/jwgfinal.pdf).

Krumnow, J. (1995) 'Das derivative Geschäft als Motor des Wandels für das Bankcontrolling', Die Betriebswirtschaft, 55(1): 11-20.

Krumnow, J., Sprißler, W., Bellavite-Hövermann, Y., Kemmer, M. and Steinbrücker, H. (1994) Rechnungslegung der Kreditinstitute, Stuttgart: Schäffer-Poeschel.

Naumann, T. (1995) Bewertungseinheiten im Gewinnermittlungsrecht der Banken, Düsseldorf: IDW-Verlag. 
Scharpf, P. and Luz, G. (2000) Risikomanagement, Bilanzierung und Aufsicht von Finanzderivaten, $2^{\text {nd }}$ edition, Stuttgart: Schäffer-Poeschel.

Wittenbrink, C. and Göbel, G. (1997) 'Interne Geschäfte - ein trojanisches Pferd vor den Toren des Bilanzrechts?', Die Bank, 5: 270-274. 
Figure 1: Risk Management of Two Customer Transactions within a Universal Bank

Trading units

Swap Desk

Non-Trading Unit
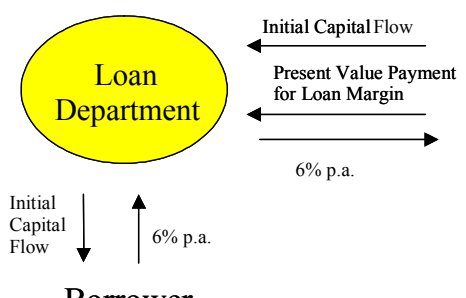

$6 \%$ p.

Borrower

A customer takes a loan of

EUR 100million

for 5 years and pays $6 \%$

interest annually

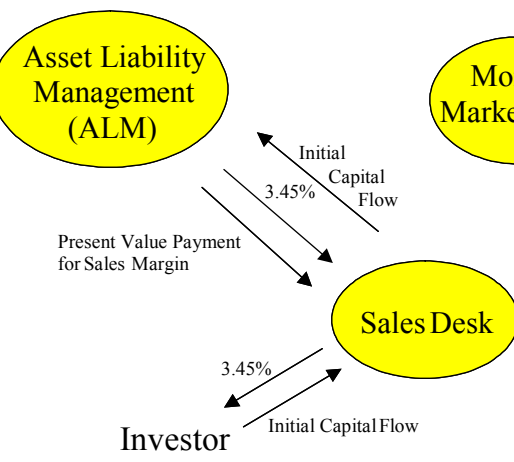

A customer deposits

EUR 50 million for 6 months 
Figure 2: $\quad$ Scenarios of Rising and Falling Interest Rates

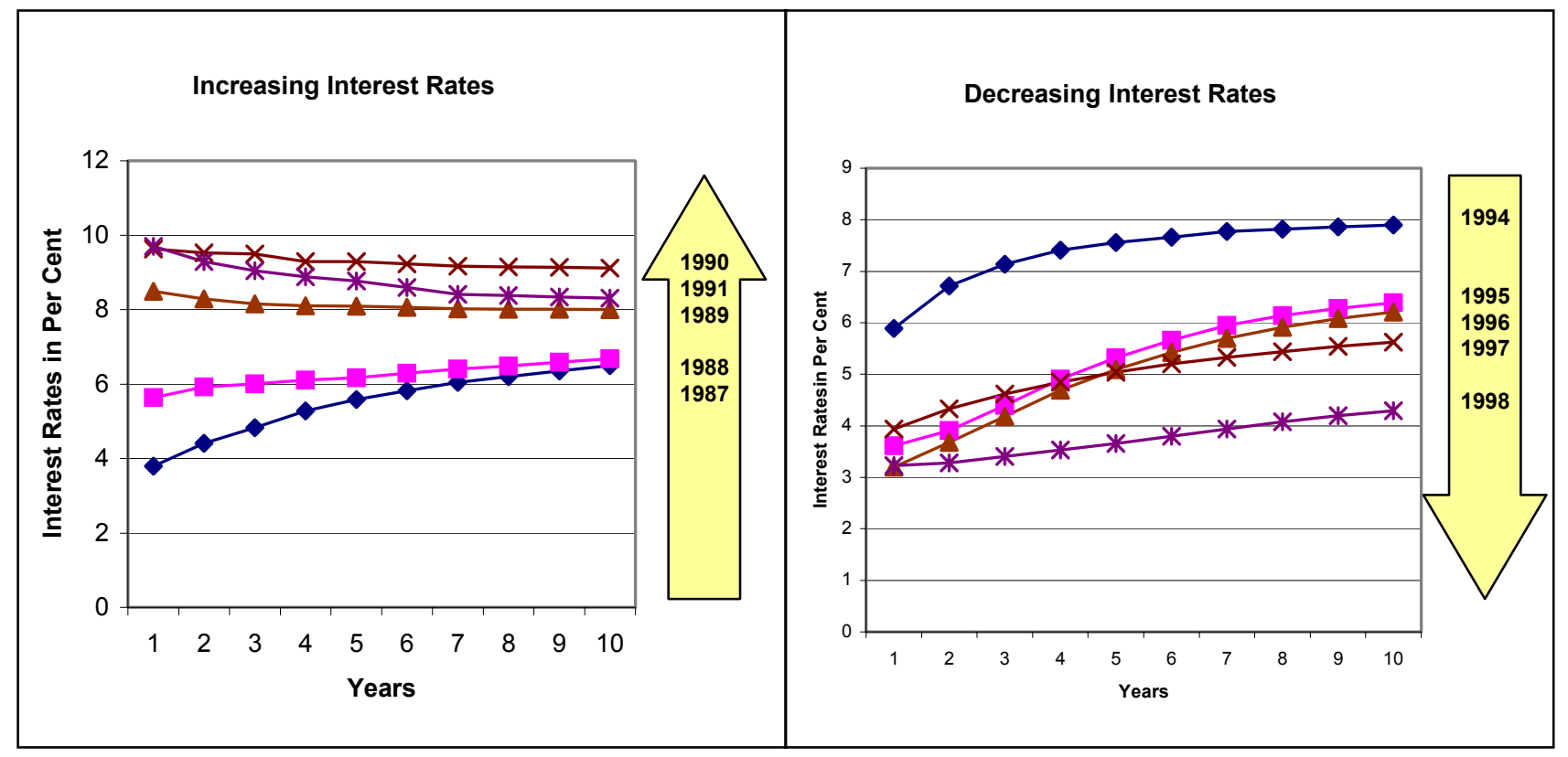


Table 1: $\quad$ Model Bank—Full Hedge: Decreasing Interest Rates (Partial Hedge: Idem, but without Transactions in Italics)

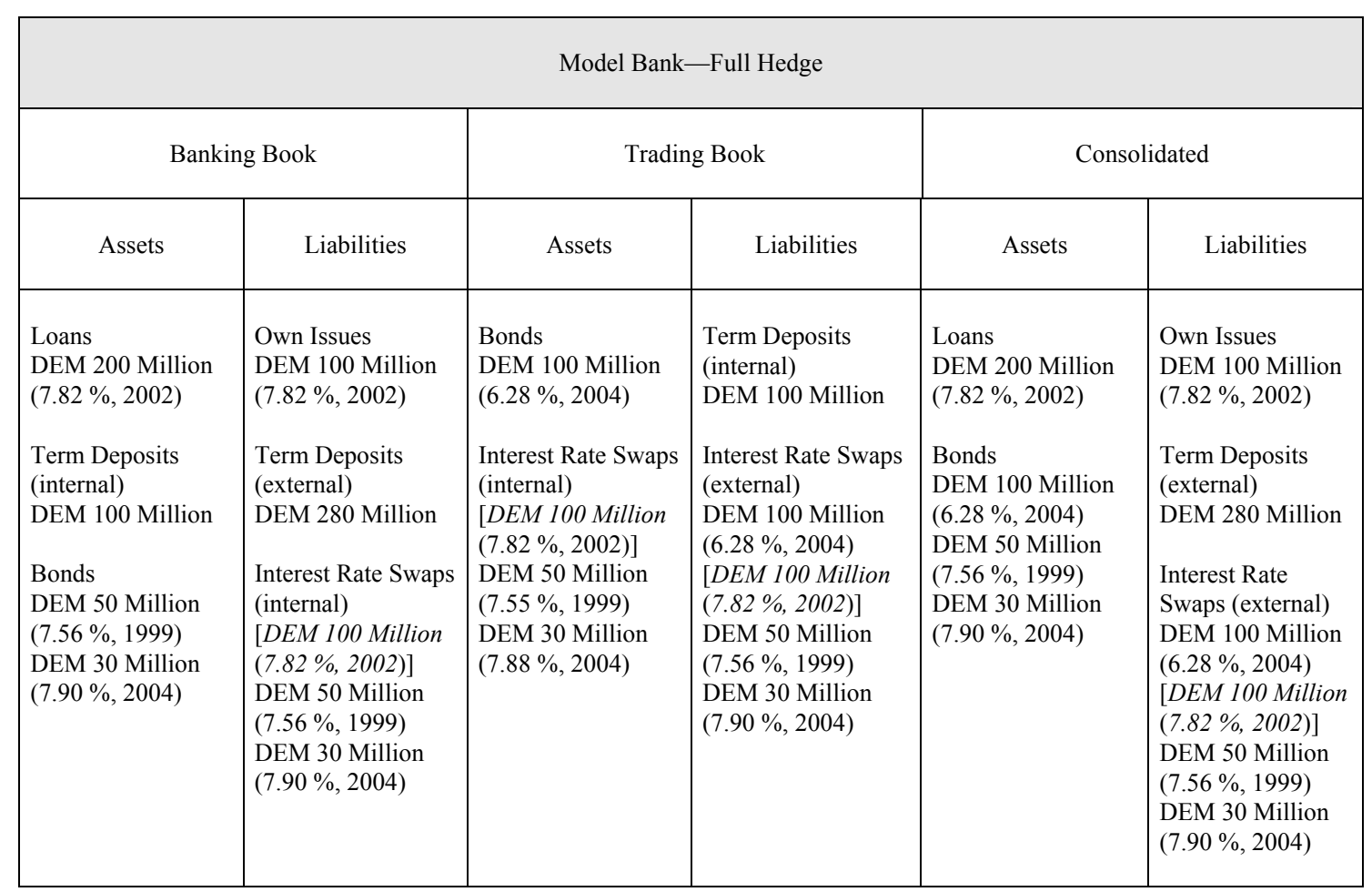


Table 2: Accounting for Financial Instruments under the Old IAS "Mixed Model"

\begin{tabular}{|c|c|c|c|}
\hline & "Trading book" & & \\
\hline \multirow[t]{3}{*}{$\begin{array}{l}\text { At fair value: } \\
\text { Gain or loss } \\
\text { recognised }\end{array}$} & $\begin{array}{l}\text { Financial Asset: } \\
\text { Maturity } 5 \text { years; } \\
\text { Fixed rate } 8.00 \text { percent }\end{array}$ & $\begin{array}{l}\text { Interest rate Swap: } \\
\text { Maturity } 5 \text { years; } \\
\text { Pay fixed rate } 8.00 \text { percent }\end{array}$ & $\begin{array}{l}\text { At fair value: } \\
\text { Gain or loss } \\
\text { recognised }\end{array}$ \\
\hline & \multicolumn{3}{|c|}{$\begin{array}{l}\text { Compensating valuation } \\
\text { Inefficiencies fully measured }\end{array}$} \\
\hline & \multicolumn{3}{|l|}{ "Banking book" } \\
\hline $\begin{array}{l}\text { At cost: } \\
\text { Gain or loss not } \\
\text { recognised }\end{array}$ & $\begin{array}{l}\text { Financial Asset (Loan): } \\
\text { Maturity } 5 \text { years; } \\
\text { Fixed rate } 8.00 \text { percent }\end{array}$ & $\begin{array}{l}\text { [Interest rate Swap: } \\
\text { Maturity } 5 \text { years; } \\
\text { Pay fixed rate } 8.00 \text { percent- } \\
\text { off- balance sheet] }\end{array}$ & $\begin{array}{l}\text { At cost: } \\
\text { Gain or loss } \\
\text { not recognised }\end{array}$ \\
\hline $\begin{array}{l}\text { At cost: } \\
\text { Gain or loss } \\
\text { not recognised }\end{array}$ & $\begin{array}{l}\text { [Interest rate Swap: } \\
\text { Maturity } 5 \text { years; } \\
\text { Receive fixed rate } 8.00 \\
\text { percent - off-balance sheet] }\end{array}$ & $\begin{array}{l}\text { Financial liability } \\
\text { (Issued Bond): } \\
\text { Maturity } 5 \text { years; } \\
\text { Fixed rate } 8.00 \text { percent }\end{array}$ & $\begin{array}{l}\text { At cost: } \\
\text { Gain or loss not } \\
\text { recognised }\end{array}$ \\
\hline \multicolumn{4}{|c|}{$\begin{array}{c}\text { Hedge Accounting: Non-valuation (“compensating misevaluation”) } \\
\text { Inefficiencies not measured }\end{array}$} \\
\hline \multirow[t]{2}{*}{$\begin{array}{l}\text { At lower of cost } \\
\text { or market: } \\
\text { Only an overhang } \\
\text { of losses } \\
\text { recognised }\end{array}$} & $\begin{array}{l}\text { Financial Asset (Security): } \\
\text { Maturity } 5 \text { years; } \\
\text { Fixed rate } 8.00 \text { percent }\end{array}$ & $\begin{array}{l}\text { [Interest rate Swap: } \\
\text { Maturity } 5 \text { years; } \\
\text { Pay fixed rate } 8.00 \text { percent- } \\
\text { off-balance sheet] }\end{array}$ & $\begin{array}{l}\text { At lower of cost } \\
\text { or market: } \\
\text { Only an overhang } \\
\text { of losses } \\
\text { recognised }\end{array}$ \\
\hline & $\begin{array}{l}\text { Hedge Accounting: } \\
\text { Inefficiencies partly me }\end{array}$ & $\begin{array}{l}\text { ompensating valuation } \\
\text { sured (zero line approach) }\end{array}$ & \\
\hline
\end{tabular}


Table 3: Accounting for Financial Instruments under the Old IAS "Mixed Model" with Internal Derivatives Hedging - Scenario of Rising Interest Rates

\begin{tabular}{|c|c|c|c|}
\hline & "Trading book" & \multirow[b]{2}{*}{$\begin{array}{l}\text { Interest rate Swap (external): } \\
\text { Maturity } 5 \text { years; } \\
\text { Pay fixed rate } 8.00 \text { percent } \\
\text { Receive variable rate }\end{array}$} & \multirow[b]{2}{*}{$\begin{array}{l}\text { At fair value: } \\
\text { Gain } \\
\text { recognised }\end{array}$} \\
\hline $\begin{array}{l}\text { Eliminated on } \\
\text { consolidation }\end{array}$ & $\begin{array}{l}\text { Interest rate Swap (internal): } \\
\text { Maturity } 5 \text { years; } \\
\text { Receive fixed rate } 8.00 \text { percent } \\
\text { Pay variable rate }\end{array}$ & & \\
\hline \multirow{3}{*}{$\begin{array}{l}\text { At cost: } \\
\text { Loss not } \\
\text { recognised }\end{array}$} & "Banking book" & & \\
\hline & \multirow[t]{2}{*}{$\begin{array}{l}\text { Financial Asset (Loan): } \\
\text { Maturity } 5 \text { years; } \\
\text { Receive fixed rate } 8.00 \text { percent }\end{array}$} & $\begin{array}{l}\text { Term Deposit } \\
\text { Maturity } 3 \text { months } \\
\text { Pay variable rate }\end{array}$ & At cost \\
\hline & & $\begin{array}{l}\text { Interest rate Swap (internal): } \\
\text { Maturity } 5 \text { years; } \\
\text { Pay fixed rate } 8.00 \text { percent } \\
\text { Receive variable rate }\end{array}$ & $\begin{array}{l}\text { Eliminated on } \\
\text { consolidation }\end{array}$ \\
\hline
\end{tabular}


Table 4: $\quad$ Comparison of Accounting Results - Fully Hedged Bank / Decreasing Interest Rates / Balance Sheet

\begin{tabular}{|c|c|c|c|c|c|c|c|c|c|c|c|c|c|c|c|}
\hline & \multirow{2}{*}{\multicolumn{3}{|c|}{\begin{tabular}{|c|} 
Panel A \\
Old IAS \\
with Hedge Accounting
\end{tabular}}} & \multirow{2}{*}{\multicolumn{3}{|c|}{\begin{tabular}{|c|} 
Panel B \\
Current IAS \\
without Hedge Accounting
\end{tabular}}} & \multirow{2}{*}{\multicolumn{3}{|c|}{$\begin{array}{c}\text { Panel C } \\
\text { Current IAS } \\
\text { with Fair Value Hedge }\end{array}$}} & \multirow{2}{*}{\multicolumn{3}{|c|}{$\begin{array}{c}\text { Panel D } \\
\text { Current IAS } \\
\text { with Cash Flow Hedge }\end{array}$}} & \multirow{2}{*}{\multicolumn{3}{|c|}{$\begin{array}{c}\text { Panel E } \\
\text { JWG Draft Standard } \\
\text { Full Fair Value }\end{array}$}} \\
\hline & & & & & & & & & & & & & & & \\
\hline & 1996 & 1997 & 1998 & 1996 & 1997 & 1998 & 1996 & 1997 & 1998 & 1996 & 1997 & 1998 & 1996 & 1997 & 1998 \\
\hline Trading Assets & 02.37 & 105.50 & 113.18 & 102.37 & 105.50 & 113.18 & 102.37 & 105.50 & 113.18 & 102.37 & 105.50 & 113.18 & 102.37 & 105.50 & 113.18 \\
\hline Loans and Advances & 200.00 & 200.00 & 200.00 & 200.00 & 200.00 & 200.00 & 212.27 & 212.12 & 215.79 & 200.00 & 200.00 & 200.00 & 224.54 & 224.24 & 231.58 \\
\hline Investment Securities & 80.00 & 83.04 & 83.04 & & & & & & & & & & & & \\
\hline $\begin{array}{l}\text { Available } \\
\text { Financial }\end{array}$ & & & & & 53.04 & 52.10 & 54.70 & 53.04 & 52.10 & 54.70 & 53.04 & 52.10 & 54.70 & 53.04 & 52.1 \\
\hline $\begin{array}{l}\text { Held to Maturity } \\
\text { Financial Instruments }\end{array}$ & & & & 30.00 & 30.00 & 30.00 & 30.00 & 30.00 & 30.00 & 30.00 & 30.00 & 30.00 & 33.82 & 34.46 & 36.54 \\
\hline Hedge Derivatives & & & & 0.00 & 0.00 & 0.00 & 0.00 & 0.00 & 0.00 & 0.00 & 0.00 & 0.00 & & & \\
\hline ("Plug") & 20.80 & 16.58 & 21.38 & 0.00 & 0.00 & 0.00 & 0.00 & 0.00 & 0.00 & 0.00 & 0.00 & 0.00 & & & \\
\hline Tota & 403.17 & 405.12 & 417.60 & 387.07 & 388.54 & 395.28 & 399.34 & 400.66 & 411.07 & 387.07 & 388.54 & 395.28 & 415.44 & 417.24 & 433.3 \\
\hline Trading $\mathrm{Li}$ & 3.17 & 25.12 & 37.60 & 23.17 & 25.12 & 37.60 & 6.19 & 9.96 & 19.71 & 2.37 & 5.50 & 13.18 & 23.17 & 25.12 & 37.60 \\
\hline Liabilities to Banks & 280.00 & 280.00 & 280.00 & 280.00 & 280.00 & 280.00 & 280.00 & 280.00 & 280.00 & 280.00 & 280.00 & 280.00 & 280.00 & 280.00 & 280.00 \\
\hline Certified Liabilities & 100.00 & 100.00 & 100.00 & 100.00 & 100.00 & 100.00 & 100.00 & 100.00 & 100.00 & 100.00 & 100.00 & 100.00 & 112.27 & 112.12 & 115.79 \\
\hline Hedge Derivatives & & & & 0.00 & 0.00 & 0.00 & 16.97 & 15.16 & 17.89 & 20.80 & 19.62 & 24.42 & & & \\
\hline Other Liabilities & 0.00 & 0.00 & 0.00 & 0.00 & 0.00 & 0.00 & 0.00 & 0.00 & 0.00 & 0.00 & 0.00 & 0.00 & & & \\
\hline Retained Earnings & 0.00 & 0.00 & 0.00 & -18.84 & -20.80 & -16.58 & -3.36 & -3.82 & -4.46 & 0.00 & 0.00 & 3.04 & 0.00 & 0.00 & 0.0 \\
\hline $\begin{array}{l}\text { Accumulated Other } \\
\text { Comprehensive Income } \\
\text { Other Comprehensive } \\
\text { Income }\end{array}$ & & & & -0.06 & $\begin{array}{r}4.70 \\
-4.70\end{array}$ & -0.94 & 0.00 & 0.00 & 0.00 & $\begin{array}{r}-14.08 \\
-2.02\end{array}$ & $\begin{array}{r}-16.09 \\
-3.53\end{array}$ & $\begin{array}{r}-19.62 \\
-5.74\end{array}$ & & & \\
\hline Net Income & 0.00 & 0.00 & 0.00 & -1.96 & 4.21 & -4.80 & -0.47 & -0.64 & -2.07 & 0.00 & 3.04 & 0.00 & 0.00 & 0.00 & 0.00 \\
\hline $\begin{array}{l}\text { Total Liabilities \& } \\
\text { Equity }\end{array}$ & 403.17 & 405.12 & 417.60 & 387.07 & 388.54 & 395.28 & 399.34 & 400.66 & 411.07 & 387.07 & 388.54 & 395.28 & 415.44 & 417.24 & 433.39 \\
\hline
\end{tabular}

Table 4: $\quad$ Comparison of Accounting Results - Fully Hedged Bank / Decreasing Interest Rates / Income Statement

\begin{tabular}{|c|c|c|c|c|c|c|c|c|c|c|c|c|c|c|c|}
\hline & \multicolumn{3}{|c|}{ Panel A } & \multicolumn{3}{|c|}{ Panel B } & \multicolumn{3}{|c|}{ Panel C } & \multicolumn{3}{|c|}{ Panel D } & \multicolumn{3}{|c|}{ Panel E } \\
\hline & \multicolumn{3}{|c|}{$\begin{array}{c}\text { Old IAS } \\
\text { with Hedge Accounting }\end{array}$} & \multicolumn{3}{|c|}{$\begin{array}{c}\text { Current IAS } \\
\text { without Hedge Accounting }\end{array}$} & \multicolumn{3}{|c|}{$\begin{array}{c}\text { Current IAS } \\
\text { with Fair Value Hedge }\end{array}$} & \multicolumn{3}{|c|}{$\begin{array}{c}\text { Current IAS } \\
\text { with Cash Flow Hedge }\end{array}$} & \multicolumn{3}{|c|}{$\begin{array}{c}\text { JWG Draft Standard } \\
\text { Full Fair Value }\end{array}$} \\
\hline & 1996 & 1997 & 1998 & 1996 & 1997 & 1998 & 1996 & 1997 & 1998 & 1996 & 1997 & 1998 & 1996 & 1997 & 1998 \\
\hline Net Interest Income & 0.00 & 0.00 & 0.00 & 7.47 & 8.21 & 6.88 & 1.29 & 1.41 & 1.19 & 0.00 & 0.00 & 0.00 & 0.00 & 0.00 & 0.00 \\
\hline Net Trading Income & 0.00 & 0.00 & 0.00 & -9.43 & -7.03 & -11.68 & -1.75 & -2.05 & -3.26 & 0.00 & 0.00 & 0.00 & 0.00 & 0.00 & 0.00 \\
\hline $\begin{array}{l}\text { Net Gains Available } \\
\text { for Sale }\end{array}$ & 0.00 & $\begin{array}{r}(3.04- \\
3.04) \\
\end{array}$ & 0.00 & 0.00 & 3.04 & 0.00 & 0.00 & 0.00 & 0.00 & 0.00 & 3.04 & 0.00 & & & \\
\hline Net Income & 0.00 & 0.00 & 0.00 & -1.96 & 4.21 & -4.80 & -0.47 & -0.64 & -2.07 & 0.00 & 3.04 & 0.00 & 0.00 & 0.00 & 0.00 \\
\hline $\begin{array}{l}\text { Other Comprehensive } \\
\text { Income }\end{array}$ & & & & -0.06 & -4.70 & -0.94 & 0.00 & 0.00 & 0.00 & -2.02 & -3.53 & -5.74 & 0,00 & 0,00 & 0,00 \\
\hline $\begin{array}{l}\text { Comprehensive } \\
\text { Income }\end{array}$ & & & & -2.02 & -0.49 & -5.74 & -0.47 & -0.64 & -2.07 & -2.02 & -0.49 & -5.74 & 0,00 & 0,00 & 0,00 \\
\hline
\end{tabular}


Table 5: Comparison of Accounting Results - Partially Hedged Bank / Decreasing Interest Rates / Balance Sheet

\begin{tabular}{|c|c|c|c|c|c|c|c|c|c|c|c|c|c|c|c|}
\hline & \multicolumn{3}{|c|}{ Panel A } & \multicolumn{3}{|c|}{ Panel B } & \multicolumn{3}{|c|}{ Panel C } & \multicolumn{3}{|c|}{ Panel D } & \multicolumn{3}{|c|}{ Panel E } \\
\hline & \multicolumn{3}{|c|}{$\begin{array}{c}\text { Old IAS } \\
\text { with Hedge Accounting }\end{array}$} & \multicolumn{3}{|c|}{\begin{tabular}{|c|} 
Current IAS \\
without Hedge Accounting
\end{tabular}} & \multicolumn{3}{|c|}{$\begin{array}{c}\text { Current IAS } \\
\text { with Fair Value Hedge }\end{array}$} & \multicolumn{3}{|c|}{$\begin{array}{c}\text { Current IAS } \\
\text { with Cash Flow Hedge }\end{array}$} & \multicolumn{3}{|c|}{$\begin{array}{l}\text { JWG Draft Standard } \\
\text { Full Fair Value }\end{array}$} \\
\hline & 1996 & 1997 & 1998 & 1996 & 1997 & $1998^{\circ}$ & 1996 & 1997 & 1998 & 1996 & 1997 & 1998 & 1996 & 1997 & 1998 \\
\hline Trading Assets & 102.37 & 105.50 & 113.18 & 102.37 & 105.50 & 113.18 & 102.37 & 105.50 & 113.18 & 102.37 & 105.50 & 113.18 & 102.37 & 105.50 & 113.18 \\
\hline Loans and Advances & 200.00 & 200.00 & 200.00 & 200.00 & 200.00 & 200.00 & 200.00 & 200.00 & 200.00 & 200.00 & 200.00 & 200.00 & 224.54 & 224.24 & 231.58 \\
\hline Investment Securities & 80.00 & 83.04 & 83.04 & & & & & & & & & & & & \\
\hline $\begin{array}{l}\text { Available for Sale } \\
\text { Financial Instruments }\end{array}$ & & & & 54.70 & 53.04 & 52.10 & 54.70 & 53.04 & 52.10 & 54.70 & 53.04 & 52.10 & 54.70 & 53.04 & 52.10 \\
\hline $\begin{array}{l}\text { Held to Maturity } \\
\text { Financial Instruments }\end{array}$ & & & & 30.00 & 30.00 & 30.00 & 30.00 & 30.00 & 30.00 & 30.00 & 30.00 & 30.00 & 33.82 & 34.46 & 36.54 \\
\hline Hedge Derivatives & & & & 0.00 & 0.00 & 0.00 & 0.00 & 0.00 & 0.00 & 0.00 & 0.00 & 0.00 & & & \\
\hline Other Assets ("Plug") & 8.53 & 4.46 & 5.60 & 0.00 & 0.00 & 0.00 & 0.00 & 0.00 & 0.00 & 0.00 & 0.00 & 0.00 & & & \\
\hline Total Assets & 390.90 & 393.00 & 401.81 & 387.07 & 388.54 & 395.28 & 387.07 & 388.54 & 395.28 & 387.07 & 388.54 & 395.28 & 415.44 & 417.24 & 433.39 \\
\hline Trading Liabilities & 10.90 & 13.00 & 21.81 & 10.90 & 13.00 & 21.81 & 6.19 & 9.96 & 19.71 & 2.37 & 5.50 & 13.18 & 10.90 & 13.00 & 21.81 \\
\hline Liabilities to Banks & 273.79 & 268.97 & 264.66 & 273.79 & 268.97 & 264.66 & 273.79 & 268.97 & 264.66 & 273.79 & 268.97 & 264.66 & 273.79 & 268.97 & 264.66 \\
\hline Certified Liabilities & 100.00 & 100.00 & 100.00 & 100.00 & 100.00 & 100.00 & 100.00 & 100.00 & 100.00 & 100.00 & 100.00 & 100.00 & 112.27 & 112.12 & 115.79 \\
\hline Hedge Derivatives & & & & 0.00 & 0.00 & 0.00 & 0.00 & 0.00 & 0.00 & 0.00 & 0.00 & 0.00 & & & \\
\hline Other Liabilities & 0.00 & 0.00 & 0.00 & 0.00 & 0.00 & 0.00 & 4.70 & 3.04 & 2.10 & 8.53 & 7.50 & 8.63 & & & \\
\hline Retained Earnings & 1.93 & 6.21 & 11.03 & -6.19 & -2.32 & 6.57 & 0.00 & 0.00 & 0.00 & 1.93 & 6.21 & 14.07 & 12.65 & 18.48 & 23.15 \\
\hline $\begin{array}{l}\text { Accumulated Other } \\
\text { Comprehensive Income } \\
\text { Other Comprehensive } \\
\text { Income }\end{array}$ & & & & -0.06 & $\begin{array}{r}4.70 \\
-4.70\end{array}$ & -0.94 & -1.43 & 0.00 & 0.00 & -0.47 & -3.68 & -2.07 & & & \\
\hline Net Income & 4.28 & 4.82 & 4.31 & 3.87 & 8.88 & 3.18 & 3.81 & 4.18 & 2.24 & 4.28 & 7.86 & 4.31 & 5.83 & 4.67 & 7.98 \\
\hline $\begin{array}{l}\text { Total Liabilities \& } \\
\text { Equity }\end{array}$ & 390.90 & 393.00 & 401.81 & 387.07 & 388.54 & 395.28 & 387.07 & 388.54 & 395.28 & 387.07 & 388.54 & 395.28 & 415.44 & 417.24 & 433.39 \\
\hline
\end{tabular}

Table 5: Comparison of Accounting Results - Partially Hedged Bank / Decreasing Interest Rates / Income Statement

\begin{tabular}{|c|c|c|c|c|c|c|c|c|c|c|c|c|c|c|c|}
\hline & \multicolumn{3}{|c|}{ Panel A } & \multicolumn{3}{|c|}{\begin{tabular}{|c|} 
Panel B \\
Current IAS
\end{tabular}} & \multicolumn{3}{|c|}{ Panel C } & \multicolumn{3}{|c|}{ Panel D } & \multicolumn{3}{|c|}{ Panel E } \\
\hline & \multicolumn{3}{|c|}{$\begin{array}{c}\text { Old IAS } \\
\text { with Hedge Accounting }\end{array}$} & \multicolumn{3}{|c|}{\begin{tabular}{|c|} 
Current IAS \\
without Hedge Accounting
\end{tabular}} & \multicolumn{3}{|c|}{$\begin{array}{c}\text { Current IAS } \\
\text { with Fair Value Hedge }\end{array}$} & \multicolumn{3}{|c|}{$\begin{array}{c}\text { Current IAS } \\
\text { with Cash Flow Hedge }\end{array}$} & \multicolumn{3}{|c|}{$\begin{array}{c}\text { JWG Draft Standard } \\
\text { Full Fair Value }\end{array}$} \\
\hline & 1996 & 1997 & 1998 & 1996 & 1997 & 1998 & 1996 & 1997 & 1998 & 1996 & 1997 & 1998 & 1996 & 1997 & 1998 \\
\hline Net Interest Income & 4.28 & 4.82 & 4.31 & 7.54 & 8.41 & 7.31 & 5.57 & 6.23 & 5.50 & 4.28 & 4.82 & 4.31 & 5.83 & 4.67 & 7.98 \\
\hline Net Trading Income & 0.00 & 0.00 & 0.00 & -3.67 & -2.56 & -4.13 & -1.75 & -2.05 & -3.26 & 0.00 & 0.00 & 0.00 & 0.00 & 0.00 & 0.00 \\
\hline $\begin{array}{l}\text { Net Gains Available } \\
\text { for Sale }\end{array}$ & 0.00 & $\begin{array}{r}(3.04- \\
3.04) \\
\end{array}$ & 0.00 & 0.00 & 3.04 & 0.00 & 0.00 & 0.00 & 0.00 & 0.00 & 3.04 & 0.00 & & & \\
\hline Net Income & 4.28 & 4.82 & 4.31 & 3.87 & 8.88 & 3.18 & 3.81 & 4.18 & 2.24 & 4.28 & 7.86 & 4.31 & 5.83 & 4.67 & 7.98 \\
\hline $\begin{array}{l}\text { Other Comprehensive } \\
\text { Income }\end{array}$ & & & & -0.06 & -4.70 & -0.94 & 0.00 & 0.00 & 0.00 & -0.47 & -3.68 & -2.07 & 0,00 & 0,00 & 0,00 \\
\hline $\begin{array}{l}\text { Comprehensive } \\
\text { Income }\end{array}$ & & & & 3.81 & 4.18 & 2.24 & 3.81 & 4.18 & 2.24 & 3.81 & 4.18 & 2.24 & 5.83 & 4.67 & 7.98 \\
\hline
\end{tabular}




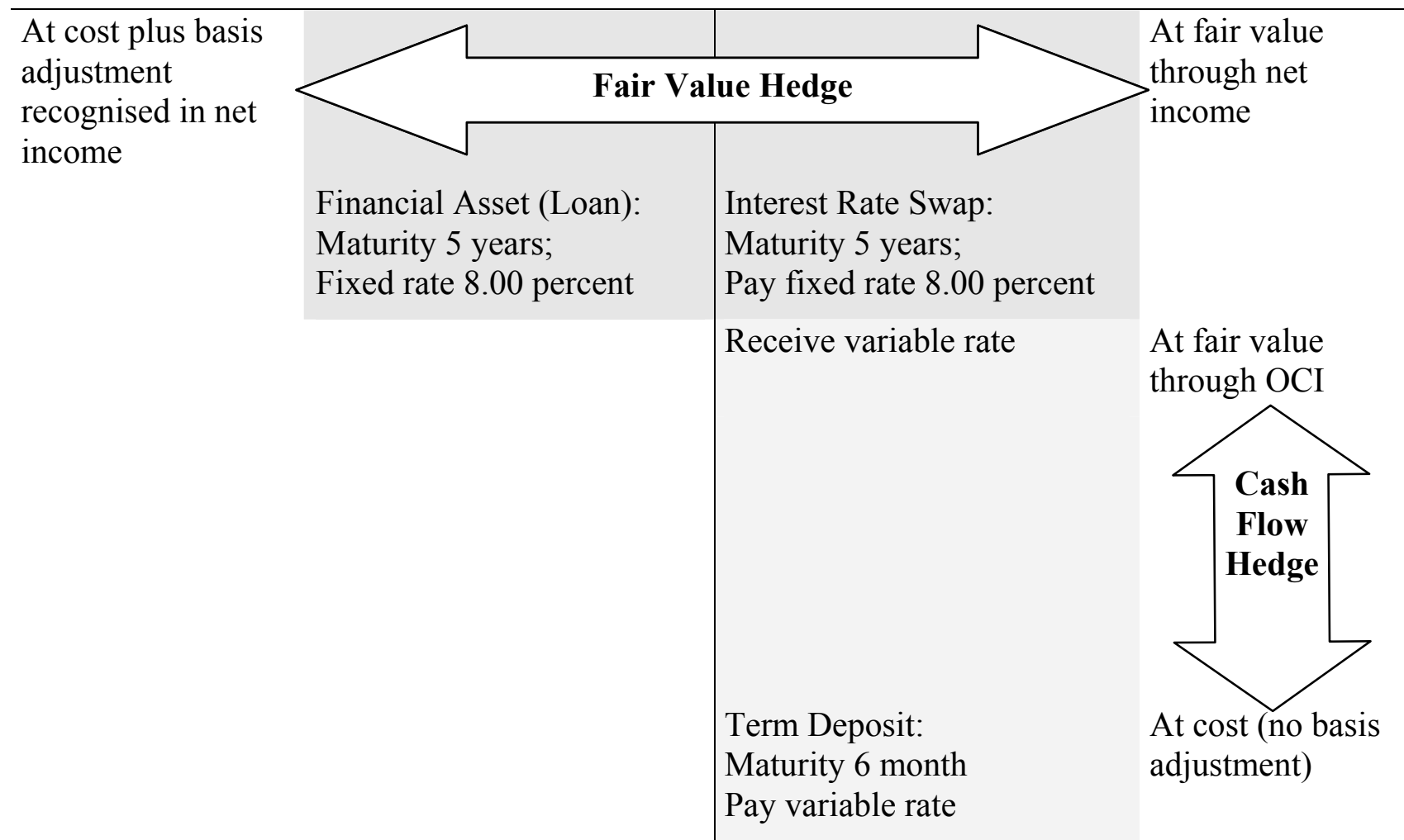

$1 \quad$ See JWG (2000).

2 See JWG (1999); Joint Working Group of Banking Associations on Financial Instruments (1999).

3 See FBE (2003), p. 7-8.

4 It would be more appropriate to refer to the "non-trading book" since the term "banking book" has a particular regulatory definition. However, in banking practice the term "banking book" rather than "non-trading book" is commonly used and in this sense, and for this reason, the term "banking book" is applied in this paper.

$5 \quad$ See also Bessis (2002), 131-89.

6 Further we use the following technical assumptions to make the model more transparent to the reader:

(4) Trade and value dates are identical and transactions may only occur on the last day of a year.

(5) There are no bid/ask spreads.

(6) The day count convention for the money and capital markets is $360 / 360$ days.

7 For quoted financial instruments measured at fair value standard setters prefer the use of current market prices. See, for example, IAS 39.99. We do not address fair value measurement issues in this paper. 
See Joint Working Group of Banking Associations on Financial Instruments (1999), 11; FBE (2003), p.7-8.

See IAS F.100 for a listing of measurement bases. IAS 39.93 confirmed the prevailing practice also under US GAAP.

10 See Krumnow et al. (1994), 452-3.

11 If classified as noncurrent assets securities need only be written down if the change in fair value is deemed to be permanent.

12 For an example of the zero line approach see Gebhardt et.al. (2002), 22.

13 We could not identify any written source, which explicitly refers to Old IAS. We refer to interpretations of the German GAAP literature Krumnow (1995), 17; Naumann (1995), 183-4; Wittenbrink and Goebel (1997), 27-8; Scharpf and Luz (2000), 242. US GAAP do not allow accounting for internal derivatives except for those transacted before 01.01.1998.

14 We do not present the analogous results for the scenario of increasing interest rates in this paper. They are reported in Gebhardt et. al. (2002).

15 See Wittenbrink and Göbel (1997), 272.

16 See Krumnow et al. (1994), 468-9.

17 See IAS 39.113; SFAS 114.13.

18 See IAS 39.9-10; SFAS 138.218.

19 OCI decreases in 1997 by 4.70 . This comprises the realised gain of 3.04 and the decrease in market value of the available for sale securities in 1997 of 1.66 .

20 Under Old IAS with hedge accounting the net payments on the internal swaps (1996: -7.47) are netted against the interest payments on the external transactions of the banking book and result in zero net interest income for all periods.

See IGC QA 121a; Bundesverband deutscher Banken (2001), 346-53.

22 See IGC QA 134-1.

23

Hedge accounting for dynamic macro hedging under Current IAS and US GAAP is further discussed in Gebhardt et.al. (2002), 34-35, 54-55, 59-60.

24 See Gebhardt (2000), 82-3.

25 
See JWG (2000), 55, 130-4. For a critique see the dissenting view of the German delegation in JWG (2000), 290; Breker, Gebhardt and Pape (2000), 741.

31 Different measurement bases will continue to exist even upon adoption of the JWG Draft Standard as most nonfinancial assets and liabilities will not be carried at fair value for the foreseeable future.

32 See amended IAS 39.18A.

33 See amended IAS 39.89B.

34 The JWG conducted a questionaire-based survey to identify critical problems in particular with regard to the reliability of fair value measurement. The conclusion was that only for certain private equity investments reliable fair value measurement was impracticable. See JWG (2000), 154. 


\section{CFS Working Paper Series:}

\begin{tabular}{|c|c|c|}
\hline No. & Author(s) & Title \\
\hline 2003/19 & $\begin{array}{l}\text { Karl-Hermann Fischer } \\
\text { Christian Pfeil }\end{array}$ & $\begin{array}{l}\text { Regulation and Competition in German Banking: } \\
\text { An Assessment }\end{array}$ \\
\hline $2003 / 20$ & $\begin{array}{l}\text { Ralf Elsas } \\
\text { Jan Pieter Krahnen }\end{array}$ & Universal Banks and Relationships with Firms \\
\hline $2003 / 21$ & $\begin{array}{l}\text { Günter Gebhardt } \\
\text { Rolf Reichardt } \\
\text { Carsten Wittenbrink }\end{array}$ & $\begin{array}{l}\text { Accounting for Financial Instruments in the } \\
\text { Banking Industry: Conclusions from a Simulation } \\
\text { Model }\end{array}$ \\
\hline $2003 / 22$ & Roman Kräussl & $\begin{array}{l}\text { Do Changes in Sovereign Credit Ratings } \\
\text { Contribute to Financial Contagion in Emerging } \\
\text { Market Crises? }\end{array}$ \\
\hline $2003 / 23$ & Roman Kräussl & $\begin{array}{l}\text { A Critique on the Proposed Use of External } \\
\text { Sovereign Credit Ratings in Basel II }\end{array}$ \\
\hline $2003 / 24$ & Tereza Tykvová & $\begin{array}{l}\text { Is the Behavior of German Venture Capitalists } \\
\text { Different? Evidence from the Neuer Markt }\end{array}$ \\
\hline $2003 / 25$ & Tereza Tykvová & $\begin{array}{l}\text { The Role of the Value Added by the Venture } \\
\text { Capitalists in Timing and Extent of IPOs }\end{array}$ \\
\hline $2003 / 26$ & $\begin{array}{l}\text { Stefanie Franzke } \\
\text { Stefanie Grohs } \\
\text { Christian Laux }\end{array}$ & $\begin{array}{l}\text { Initial Public Offerings and Venture Capital in } \\
\text { Germany }\end{array}$ \\
\hline $2003 / 27$ & Andreas Hackethal & German banks - a declining industry? \\
\hline $2003 / 28$ & $\begin{array}{l}\text { Frank A. Schmid } \\
\text { Mark Wahrenburg }\end{array}$ & $\begin{array}{l}\text { Mergers and Acquisitions in Germany-Social } \\
\text { Setting and Regulatory Framework }\end{array}$ \\
\hline $2003 / 29$ & Christina E. Bannier & Privacy or Publicity - Who Drives the Wheel? \\
\hline
\end{tabular}

